\title{
COPING STRATEGIES AND SOCIAL PROBLEM SOLVING IN ADOLESCENCE
}

\author{
INTRODUCTION
}

Social competence has traditionally been defined as the complex system of social abilities, habits, skills and knowledge (e.g. Rose-Krasnor, 1997; SemrudClikeman, 2007). Social competence has the function to organise social behaviour, and to trigger the operation of the individual elements of the system (Nagy, 2007). International surveys agree that social competence is a very important factor for both individuals' inner balance and a satisfactory social coexistence. Within social competence the functioning of social problem solving and coping strategies are very relevant. However, the investigation of this social components is not very common in Hungary, thus we do not have adequate data about this area. Their developmental effect must be investigated because these results are very important for planning a social competence promotion program in schools.

\section{THEORETICAL BACKGROUND}

According to the well-established psychological view, social competence is a complex system of various social, emotional, cognitive (both inherited and learnt) abilities and motives (Rose-Krasnor, 1997). Within social competence social-problem solving and coping strategies are very important factors (Fülöp, 2009). According to D'Zurilla et al. (2002. 14.), the social problem solving (SPS) is "the self-directed cognitive-behavioural process by which a person attempts to identify or discover effective or adaptive ways of coping problematic situations encountered in the course of everyday living". Based on the MaydeuOlivares and D'Zurilla's research (1996), SPS has five different factors: positive problem orientation, negative problem orientation, rational problem solving, impulsivity/carelessness, and avoidance. Longitudinal studies with adults suggest that negative orientation predicts future depression, anxiety and stress (Ciarrochi $\&$ Scott, 2006). According to Ciarrochi et al. (2009), some adolescents also experience an increasingly negative orientation, and the negative orientation is in connection with worsening affect. Adolescents with higher levels of positive orientation had higher levels of positive emotional and empathy. Higher levels of positive orientation were also related to better family quality of life (fewer parent-adolescent social problems and conflicts). The parents-adolescent 
relationship has an important and positive effect on relationship with peers and on social problem solution in school. D'Zurilla and Nezu (1990) suggested that having rationality improve the social behaviour of both children and adults. Rationality reduces impulsivity, as measures of impulsivity remained lower at one year follow up (e.g. Shure, 1999). However, some results (e.g. Cooper, 2011) indicated that having rationality alone does not improve behaviour in adolescence; for example, the early adolescents (11-year-olds) reported strong rationality and high aggressive behaviour (Kasik, 2014, p. 144).

Coping strategies are essential components of social behaviour. Several coping strategies can be used in different frustrating situations, and both aggressive and prosocial behaviours have their role in coping (e.g. Margitics \& Pauwlik, 2006). By applying coping strategies the individual makes cognitive and behavioural efforts to solve the particular situation (Englert, Bertrams, \& Dickhauser, 2011). The frequency and efficiency of the use of different coping techniques have been identified mainly in teenagers and adults but according to recent research results coping models contain several elements which can be found at an earlier age, even in nursery-school children.

According to Lazarus and Launier (1978) as well as Lazarus and Folkman (1984), individuals use two basic types of coping technique: the problem-focused and the emotion-focused strategies. In the case of the problem-focused technique the individual makes an attempt to solve, avoid or modify the problem by focusing on the problem or the situation in order to be able to avoid it in a similar situation. During the coping process the individual can apply several coping strategies, which may aim at the problematic situation and also on the individual or individuals themselves, and their application is in close relation with the development of several cognitive areas, for example the development of problem-solving skills. In the case of the emotion-focused strategy the main purpose is to resolve and soothe emotional reactions evoked by certain situations, and to surmount overwhelming negative emotions, moreover, we also use this strategy when the situation cannot be changed (Lazarus, 1990). The application of this strategy also depends on the level of development of cognitive areas, however the relation is smaller-scale than in the other strategy, and the emotion-focused strategy is in a closer relation with how the nervous system works.

\section{AIMS AND HYPOTHESES}

The aim of our research was to explore the functioning of coping strategies and social problem solving ability at the ages of $8,12,15$ and 18 , to reveal associations between these social forms and some background factors, such as age, gender, school success (grade average) and family background (e.g. mothers' and fathers' educational level, family type), and to investigate the relationship between raters' judgements.

We hypothesised that significant differences would be found between the younger $(8,12)$ and the older $(15,18)$ cohorts; to find out about how raters' responses (children's, teachers', and mothers') relate to each other. Based on our earlier findings (Zsolnai, Lesznyák, \& Kasik, 2011; Zsolnai, Kasik, \& Braunitzer, 2014) we hypothesised that the social problem solving and coping strategies are influenced the most by family type; and the correlation between the 
ZSOLNAI \& KASIK

school success (grade average) and coping strategies and social problem solving shows increasing tendency.

\section{PARTICIPANTS AND INSTRUMENTS}

The participants were 888 students $(8: 222 ; 12: 210 ; 15: 221 ; 18: 235$ - whole simple: male $46 \%$; female $54 \%$ ) and their teachers ( $\mathrm{N}=34$ - one per group) and mothers $(\mathrm{N}=888)$. The native language of all participants was Hungarian. Two questionnaires were adapted (CSQ, Coping Strategies Questionnaire for children and teacher - Tremblay et al., 1992; SPSI, Social Problem Solving Inventory for children, mothers, teachers - D'Zurilla, Nezu, \& Maydeu-Olivares, 2002). These instruments proved to be highly reliable (Cronbach $\alpha$ are between .83 and .92).

The Tremblay questionnaire assesses social and emotional skills involved in the operation of coping strategies by items that represent problematic social situations either for the children themselves or their mates. The items are grouped into four categories: disruptive (13 items), anxious (5 items), inattentive (4 items) and prosocial (10 items). In our study, the reactions of the children were coded into seven, literature-based categories (e.g. Fabes \& Eisenberg, 1992). These categories were solely behavioural and we did not code cognitive coping responses. The behavioural coping categories used were as follows: Asking for help (adult); Asking for help (peer); Overt aggression; Verbal aggression; Avoidance; Impulsivity; Negotiation. Each response category received a proportion score ranging from 0 to 1 .

The SPSI assesses the five factors of SPS: PPO = Positive Problem Orientation; NPO = Negative Problem Orientation; RPS $=$ Rational Problem Solving; ICS = Impulsivity/Carelessness Style; AS = Avoidance Style. All factors include 5 items (resulting in a total of 25 items). PPO covers elements of constructive problem solving, such as self-efficacy and positive outcome expectancy. NPO covers a set of dysfunctional cognitive-emotional schemas like low self-efficacy and negative outcome expectancy. RPS can be defined as a constructive problem solving style that is characterized by rational, deliberate, and systematic application of effective problem-solving skills. ICS is a set of dysfunctional problem solving attempts like impulsivity and carelessness. AS is a dysfunctional dimension characterized by passivity and attempts to shift the responsibility of problem solving to others. The SPSI subscales consist of 5point (from 0 to 4 ) Likert-type items where: $0=$ Not at all true of me; $1=$ Slightly true of me; 2 = Moderately true of me; $3=$ Very true of me; $4=$ Extremely true of me.

\section{RESULTS}

Functioning of Social problem solving (SPS) and Coping strategies (CS)

The relationship between children's and mothers' responses is the strongest in most cases, and the largest divergence is observed between teachers' and parents' responses. Based on the total values (means of the raters' judgements), three SPS factors (negative problem orientation, rational problem solving and avoidance) show increasing tendency with age, contrary to positive problem 
orientation and impulsivity $(\mathrm{p}<.05)$. Gender differences can be found especially among children between 15 and 18 (for example the 15- and 18-year-old boys show more rationality than girls, and girls show more avoidance than boys).
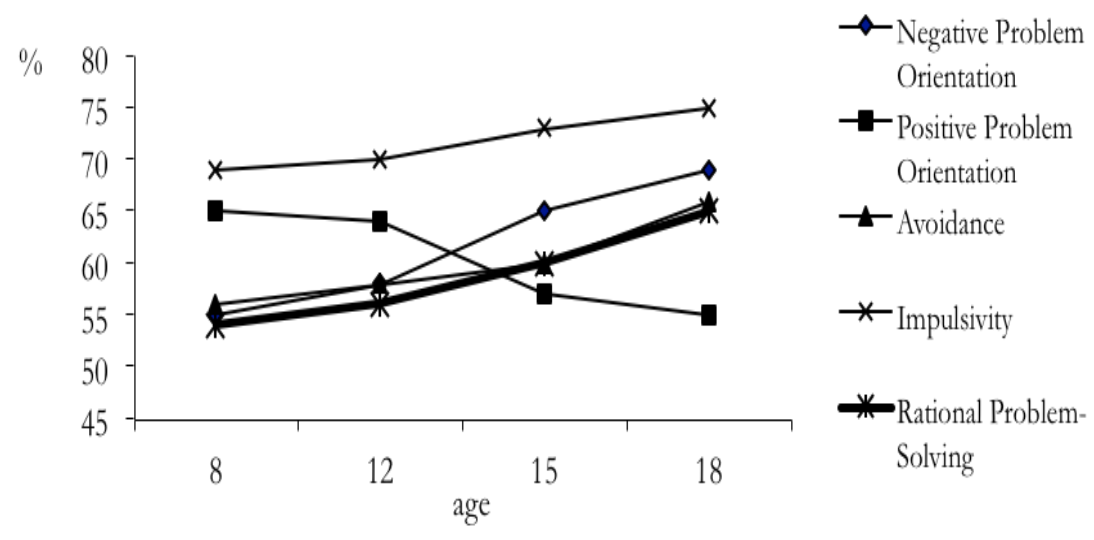

Figure 1. Social problem solving (based on the total values)

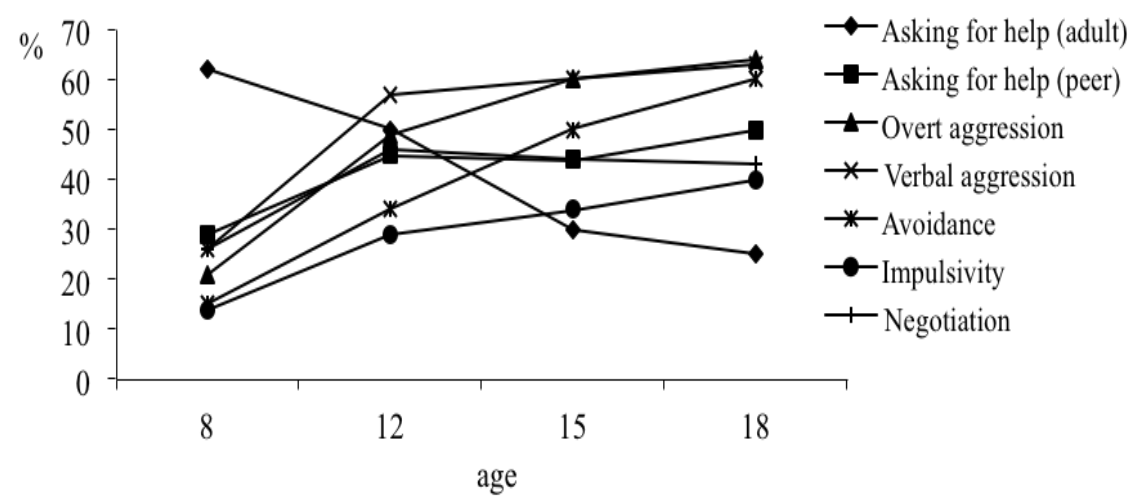

Figure 2. Coping strategies

The relationship between the values of CS of children and adults is similar in the age groups. Overt aggression, impulsivity and avoidance were used by the two older $(15,18)$ groups in a significantly higher proportion than by the two younger $(8,12)$ groups. Asking for help (peer), verbal aggression, impulsivity and negotiation were used by the older $(12,15,18)$ children in a significantly higher proportion than by the youngest (8) children. In contrary, asking for help (adult) was used by the younger $(8,12)$ children in a significantly higher 
ZSOLNAI \& KASIK

proportion than by the older $(15,18)$ children. In the oldest age group $(18)$, boys were rated significantly more aggressive than girls.

\section{Relationship SPS factors, CS, family background and school success}

The values between positive problem orientation and rationality, impulsivity and negative problem orientation are positive (Pearson $r$ are between .23 and .44) in all age groups and in the case of all raters. The correlation between rationality and avoidance, impulsivity and rationality are negative (Pearson $r$ are between .27 and -.37 ) in all age groups and in the case of all raters.

The correlations between overt and verbal aggression, avoidance and negotiation are positive (Phi $\mathrm{r}$ are between .22 and 73) in all age groups and in the case of all raters. Based on the total values, the SPS factors and CS are influenced the most by family type, and less by mothers' educational level in all age groups. In the youngest group, school success (grade average) already shows high positive correlation with SPS factors and CS, and these values increase with age. In the older $(15,18)$ groups, the highest values can be found between rational problem solving and mathematics and biology, between impulsivity and history and literature.

\section{CONCLUSION}

According to our results, (1) negative problem orientation, rational problem solving and avoidance show increasing tendency with age; (2) overt aggression, impulsivity and avoidance as coping strategies were used by older children in a significantly higher proportion than by younger children; (3) family characteristics (family type, mothers' educational level) play a major role in the development of social problem solving and coping strategies, school success shows positive correlation with social problem solving and coping strategies, and these values increase with age. These results strengthen unequivocally international research experience in the same domain (Englert et al., 2011; Fiske, 2004; Pruitt, 1998).

It is essential for researchers and educators to have appropriate and sufficient knowledge on the development of coping strategies and social problem solving, as this can inform the development of adequate learning environments for children. It is still a research issue to decide at what ages can coping strategies and social problem solving be developed most effectively.

\section{ACKNOWLEDGEMENTS}

The research reported here would not have been possible without the funding of TÁMOP 3.1.9/08/01-2009-0001. 
Ciarrochi, J. \& Scott, G. (2006). The link between emotional competence and well-being: a longitudinal study. British Journal of Guidance and Counselling, 34, 231-244.

Ciarrochi, J., Leeson, P., \& Heaven, P. C. L. (2009). A longitudinal study into the interplay between problem orientation and adolescent well-being. Journal of Counseling Psychology, 56, 441-449.

Cooper, J. O. (2011). Aggression and Rational Problem-Solving Skills of Early Adolescence. UMI Dissertation Publishing.

D’Zurilla, T. J. \& Nezu, A. M. (1990). Development and preliminary evaluation of the Social Problem-Solving Inventory. Psychological Assessment: A Journal of Consulting and Clinical Psychology, 2, 156-163.

D’Zurilla, T. J., Nezu, A., \& Maydeu-Olivares, A. (2002). Social Problem-Solving Inventory-Revised (SPSI-R): Technical Manual. North Tonawanda, NY: Multi-Health Systems.

Englert, C, Bertrams, A. \& Dickhauser, O. (2011). Dispositional self-control capacity and trait anxiety as relates to coping style. Psychology, 2(6), 598-604.

Fiske, S. T. (2004). Social beings. Care motives in social psychology. West Sussex: John Wiley \& Sons.

Fülöp, M. (2009). Socialization for cooperative and competitive citizen: a classroom observation study. Social Science Tribune. From a national identity to a European one. 55(19), 59-87.

Kasik, L. (2014). Development of Social Problem Solving - A Longitudinal Study (2009-2011) in a Hungarian Context. European Journal of Developmental Psychology, 12(2), 142-158.

Lazarus, R. S. \& Folkman, S. (1984). Stress, Appraisal, and Coping. New York: Springer.

Lazarus, R. S. \& Launier, R. (1978). Stress related transactions between person and environment. In L. Pervin \& M. Lewis (Eds.), Internal and external determinants of behaviour (pp. 126-149). New York: Plenum Press.

Lazarus, R. S. (1990). Stress, coping and illness. In H. S. Friedman (Ed.), Personality and disease (pp. 84-86). New York: Wiley.

Margitics, F. \& Pauwlik, Zs. (2006). Megküzdési stratégiák preferenciájának összefüggése az észlelt szülöi nevelöi hatásokkal. [The relationship between the preference of coping strategies and perceptions of parenting] Magyar Pedagógia, 106(1), 43-62.

Maydeu-Olivares, A. \& D'Zurilla, T.J. (1996). A factor-analytic study of the Social Problem-Solving Inventory: An integration of the theory and data. Cognitive Therapy and Research, 20(6), 115133.

Nagy, J. (2007). Kompetencia alapú kritériumorientált pedagógia. [Criterion referenced pedagogy] Szeged: Mozaik Kiadó.

Pruitt, D. G. (1998). Social conflict. In T. D. Gilbert, S. T. Fiske, \& G. Lindzey (Eds.): Handbook of social psychology (pp. 470-503). New York: McGraw-Hill.

Rose-Krasnor, L. (1997). The nature of social competence: A Theoretical review. Social Development, 6. 111-135.

Semrud-Clikeman, M. (2007): Social competence in children. New York: Springer.

Shure, M. B. (1999). I Can Problem Solve. An Interpersonal Cognitive Problem-Solving Program. National Institute of Mental Helalth, Washington.

Tremblay, R. E., Masse, B., Perron, D., \& Leblanc, M. (1992). Early disruptive behavior, poor school achievement, delinquent behavior and delinquent personality: Longitudinal analyses. Journal of Consulting and Clinical Psychology, 60, 64-72.

Zsolnai, A., Kasik L., \& Braunitzer, G. (2014). Coping strategies at the ages 8, 10 and 12. Educational Psychology | DOI: 10.1080/01443410.2014.916397

Zsolnai, A., Lesznyák, M., \& Kasik, L. (2011). Preschool children’s aggressive and prosocial behavior in stressful situations. Early Child Development and Care, 181(11), 1503-1522.

\author{
Anikó Zsolnai \\ Institute of Education, University of Szeged, Hungary \\ László Kasik \\ Institute of Education, University of Szeged, Hungary
}

